\title{
Waste to treat waste of landfill leachates
}

\author{
Abdelkader Anouzla*, Salah Souabi, Mohamed Safi, Younes Abrouki, Hayat Loukili, \\ Hicham Rhbal
}

Laboratoire de Génie de l'Eau et de l'Environnement, Faculté des Sciences et Techniques de Mohammedia, Maroc

\section{Email address:}

aanouzla@gmail.com (A. Anouzla)

\section{To cite this article:}

Abdelkader Anouzla, Salah Souabi, Mohamed Safi, Younes Abrouki, Hayat Loukili, Hicham Rhbal. Waste to Treat Waste of Landfill Leachates. International Journal of Environmental Protection and Policy. Vol. 2, No. 2, 2014, pp. 50-53.

doi: $10.11648 /$ j.ijepp.20140202.12

\begin{abstract}
This study treated the waste valorisation of steel industrial wastewater (SIWW) rich of ferric chloride as an original coagulant for removal of landfill leachates. The study also compares the different dosage of SIWW with ferric chloride. Jar-test experiments were employed in order to determine the optimum condition for the removal of organic matter. The effect of different dosages of SIWW in contamination with classic coagulant was also studied. The results reveal that lower $\mathrm{pH}$ values less than 5 enhance removal efficiency of contaminants. The percentage removal of $56,78.3$ and $72 \%$ of COD, BOD5 and NTK respectively were achieved by addition to $7 \mathrm{ml} / 1$ SIWW. 54.4, 76.7 and 70\% removal of COD, BOD5 and NTK respectively were achieved by addition to $1200 \mathrm{mg} / \mathrm{l}$ classic coagulant. The volume of sludge produced, was lower compared to classic coagulant.
\end{abstract}

Keywords: Landfill Leachates, Steel Industrial Wastewater, Ferric Chloride, Coagulation-Flocculation, Jar-Test

\section{Introduction}

One of the most important problems in designing and maintaining a landfill is managing the leachate that is generated when water passes through the waste. The leachates consist of many different organic matters (biodegradable, but also refractory to biodegradation), where humic-type constituents consist of an important group [1] as well as ammonia-nitrogen, heavy metals, chlorinated organic and inorganic salts [2].

The characteristic of landfill leachates is a combination result of complex number of factors including soil properties, weathering conditions, garbage composition. The composition and concentration of contaminants are influenced by the type of deposited wastes, the quality of refuse, hydrogeological factors and mainly by the age of landfill [3]. Regardless of the nature of the compounds, they constitute a potential pollution problem for local ground and surface waters.

Many technologies have been applied to remove the pollution of leachates [4,5]. Most of the treatment processes for wastewater treatment could be adapted for leachate treatment. The potential methods are biological (aerobic, anaerobic) and physico-chemical (precipitation, oxidation, adsorption, stripping, reverse osmosis).
The leachate quality plays a key role in choosing the method and level of treatment [6]. According to [7], physico-chemical treatment is not appropriate to treat leachate from young landfills (first several years of operation) since this young leachate is derived from complex biodegradation organics and simple dissolved organics. The important aim readily biodegradable organic content of leachate from young landfills makes it amenable to biological treatment [8]. Since the concentration of several parameters contained in young leachate can inhibit biological processes, a physico-chemical pre-treatment of this type of leachate was considered as the most popular method in order to meet the standard limits for discharge [9]. In addition to their use as a pre-treatment technique, physico-chemical processes are effective in the treatment of stabilized leachate from old landfills [10].Since old leachate contains refractory organics generally formed by bacterial or chemical processes, it is more amenable to treatment using physico-chemical processes rather than biological. It is apparent that neither biological nor physico-chemical treatment processes separately achieve high removal efficiencies and the treatment processes are site specific since the leachate composition varies from site to site with 
seasonal variations.

The Coagulation-flocculation processes [11] used the ferric chloride, the aluminium sulphate, the ferrous sulphate and the ferric chlorosulphate are commonly using coagulants. Iron salts seem more efficient than aluminium ones. The percentage removal of COD and TOC obtained by coagulation-flocculation is generally $10-25 \%$ with young leachates, but are the highest (50-65\%) with leachates of low BOD5/COD ratio (stabilised leachates or leachates pretreated by biological processes). Nonionic, cationic or anionic polyelectrolyte can use a coagulant aids to increase floc settling rate, without improving really turbidity removal efficiency.

The main objection of this study was the valorisation of steel industrial wastewater (SIWW) as an original coagulant [12] for removal of landfill leachates. The experiments were carried out by jar test are usually used. In the jar tests, $\mathrm{pH}$ and coagulant dosage were the factors that need to be determined by the optimum condition for the removal of pollution; turbidity, colour, COD, BOD5 and NTK.

\section{Materials and Methods}

\subsection{Experimental}

The equipment used was a laboratory flocculator, solutions were observed in 4 parallel jars. All solutions were stirred for $5 \mathrm{~min}$ at $150 \mathrm{rpm}$ and after this were stirred for 15 min at $75 \mathrm{rpm}$ and then 30-120 min finally was allowed to settle. Once the experiment performed in jar test, the beaker contents are transferred to special graduated conical containers (Imhoff cones).

The $\mathrm{pH}$ value was adjusted to the desired value with $\mathrm{H} 2 \mathrm{SO} 4$ and $\mathrm{NaOH}$ after the coagulant was added. The physico-chemical parameters (turbidity, colour, COD, BOD5, NTK and other) for wastewater characterisation measurement were performed according to standardised methods [13].

\subsection{SIWW Characteristics}

The SIWW was taken from Magreb Steel (Morocco society) and was used as an original coagulant in this study. The characteristics of SIWW are given in Table 1.

Table 1. The characteristics of SIWW

\begin{tabular}{ll}
\hline Parameter & Value \\
\hline $\mathrm{FeCl}_{3}$ & 1787 \\
$\mathrm{Conductivity}(\mathrm{ms} / \mathrm{cm})$ & 26200 \\
$\mathrm{pH}$ & $<1$ \\
\hline
\end{tabular}

Analysis of SIWW sampled at end pipe of this plant indicates a high level of $\mathrm{FeCl} 3$. Then this rejection was valorised as coagulant in the treatment of landfill leachates.

\subsection{Landfill Leachates Characteristics}

Leachate samples were taken from Mesbahait landfill of Mohammedia city (Figure 1).

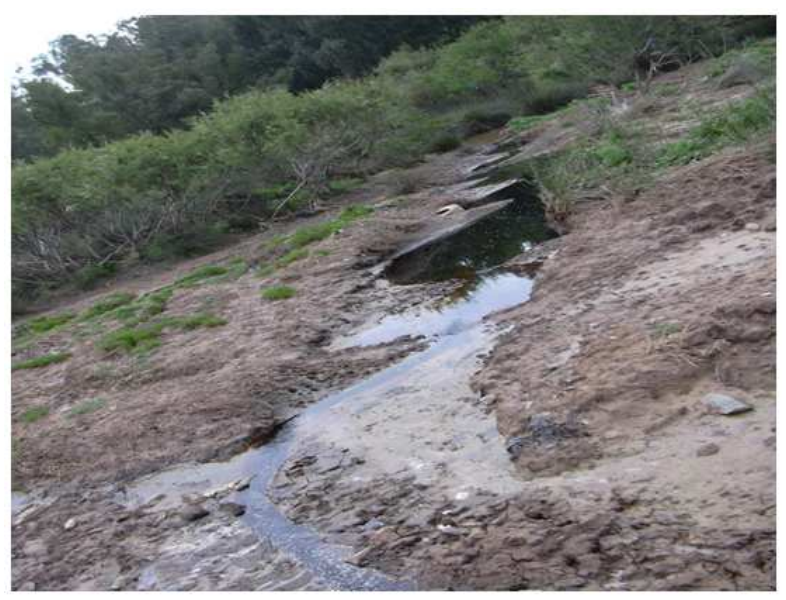

Fig 1. Leachate migration from landfill could be a potential source of surface and groundwater contamination.

This landfill receive 55200 tons of waste in 2005, 59200 tons in 2006, 59800 tons in 2007 and 19500 tons until March 2008. The characteristics of raw leachates from old detention pond at landfill of Mohammedia city are given in Table 2 .

Table 2. The characteristics of landfill leachates

\begin{tabular}{lll}
\hline Parameter & Unit & Value \\
\hline BOD5 & $\mathrm{mg} / \mathrm{L}$ & 246 \\
COD & $\mathrm{mg} / \mathrm{L}$ & 4720 \\
Suspended Solid & $\mathrm{mg} / \mathrm{L}$ & 826 \\
Turbidity & $\mathrm{NTU}$ & 520 \\
$\mathrm{pH}$ & - & 7.8 \\
$\mathrm{NTK}$ & $\mathrm{mg} / \mathrm{L}$ & 1079 \\
PO43- & $\mathrm{mg} / \mathrm{L}$ & 15.5 \\
Iron & $\mathrm{mg} / \mathrm{L}$ & $4.1-19.5$ \\
Copper & $\mathrm{mg} / \mathrm{L}$ & 4.6 \\
Conductivity & $\mathrm{mg} / \mathrm{cm}$ & 0.6 \\
\hline
\end{tabular}

\section{Results and Discussion}

\subsection{Effect of $\mathrm{pH}$}

Turbidity removal is one of the important steps in water treatment process, which is generally achieved using coagulants. Many coagulants are widely used in conventional water treatment processes, based on their chemical characteristics.

On the reduction optimal of turbidity was investing with adding any coagulant (SIWW or $\mathrm{FeCl} 3$ ). Fig. 2 presents the effect of $\mathrm{pH}$ values on the coagulation. The result indicated that the higher reduction was obtained at lower $\mathrm{pH}$. 


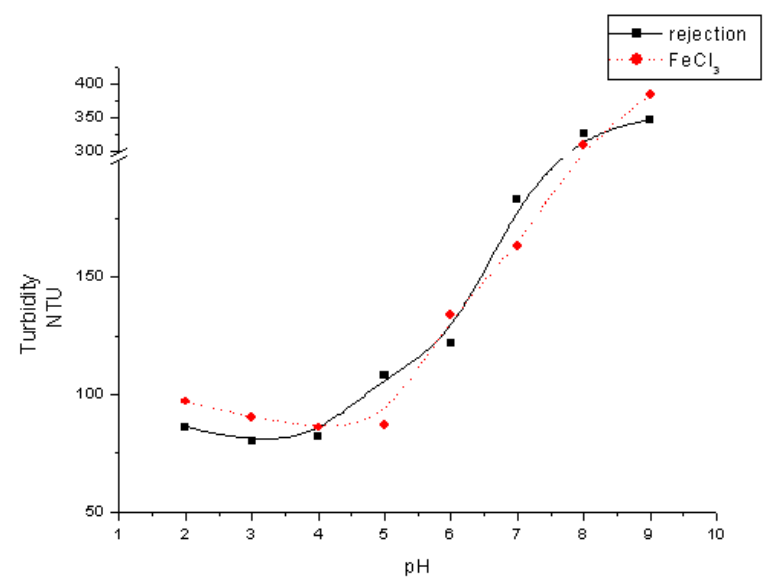

Fig 2. Effect of $p H$ on the turbidity removal of Leachate.

Extending the optimal $\mathrm{pH}$ range allows efficient performance in the face of changing effluent characteristics or any $\mathrm{pH}$ variations that may occur during the coagulation process and avoid the need to adjust $\mathrm{pH}$. The optimal $\mathrm{pH}$ values found can be related to $\mathrm{pH}$ at zero point of charge, at which the surface is change and becomes neutral. At began the $\mathrm{pH}$ surface is negatively charged, while at high $\mathrm{pH}$ it is positively charged. The isoelectric point of SIWW and $\mathrm{FeCl} 3$ are about 3 and 4 respectively. Above this $\mathrm{pH}$, positively charged flocs would prevail, which would destabilize the colloids.

\subsection{Dosage of coagulant}

Once the optimal $\mathrm{pH}$ for each coagulant had been determined experiments were performed varying the dosage of coagulant classic between 100 and $1500 \mathrm{mg} / \mathrm{l}$ and the dosage of SIWW between 1 and $10 \mathrm{ml} / 1$ in order to ascertain the influence on the coagulant process and to determine the optimal dosage (Fig. 3).

The result for Fig. 3 indicated that the colour of leachates turned from black to light brown. The optimum dose of coagulant is defined as value above which there is no significant increase in removal efficiency with further addition of coagulant.

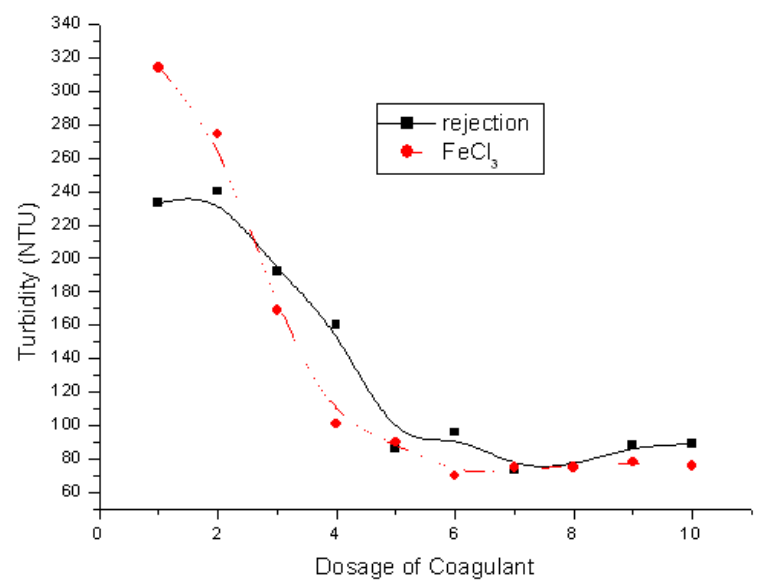

Fig 3. Effect of coagulant dosage on the turbidity removal of Leachate

\subsection{Volume of Sludge}

In addition to pollution removal, sludge production is considered in this work, as it may affect the economic feasibility of the proposed method. In the solid separation, sludge dewatering has been pointed out as one of the most expensive processes. In order to compare the results obtained using SIWW and classic coagulant, the ratios between the amounts of sludge produced and the percent of COD or colour removal has been estimated (Fig. 4).

Fig. 4 shows that SIWW produces the least amount sludge for a given amount COD and colour removed compared to $\mathrm{FeCl} 3$.

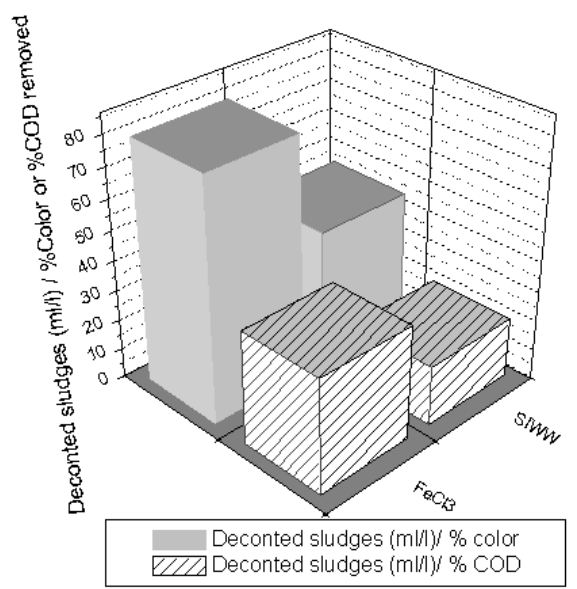

Fig 4. Ratio between the amount of sludge produced by SIWW or FeCl3 and COD or color reduction

\subsection{Comparisons of FeCl3 and SIWW}

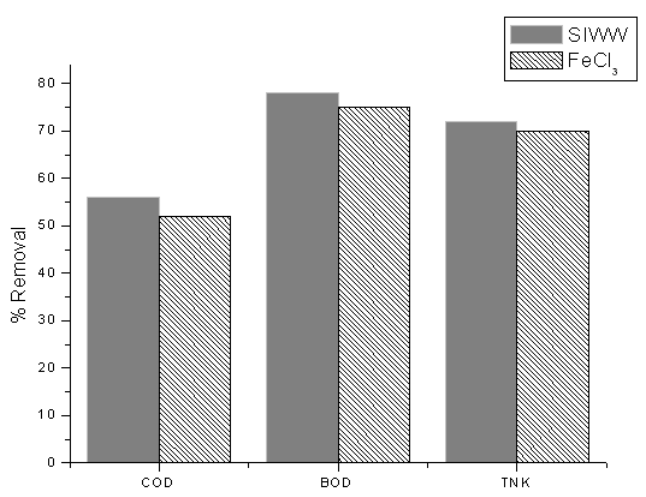

Fig 5. Comparison of SIWW and iron chloride

The parameters were determined using the optimal conditions for the coagulants $(\mathrm{FeCl} 3)$ classic and rejection industrial SIWW. Through, DCO, NTK and BOD5 values are reduced irrespective of the dye solution

The initial amount present in the leachates was $\mathrm{TKN}=$ 1079 while the removal performances obtained are 302 by SIWW and 324 by $\mathrm{FeCl} 3$. NTK removal through the coagulation process is related to removal of colloidal matter.

The efficiency of the removal of organic matter (expressed as COD and BOD5) by SIWW are similar classic coagulant $\mathrm{FeCl} 3$. 
The removal of organics from the leachate sample is associated with the removal mechanisms of humic substances by the application of coagulation process. It is well known that humic substances can be effectively removed from aqueous solutions by adding hydrolyzing coagulants. Especially the case of waters containing high amount of organic matter, there is often a stoichiometric relation between the organic content and the required coagulant dosage [14]. There are two main mechanisms regarding the removal of humic substances from the aqueous phase by the application of coagulation/flocculation:

$>$ Binding of cationic metal species to anionic sites, resulting in the neutralization of humic substances and the reduction of their solubility, and

$>$ Adsorption of humic substances onto the produced amorphous metal hydroxide precipitates.

The advantage of used SIWW treat waste of landfill leachates was optimal as well from an economic; the treatment by rejection SIWW are mainly simplicity, no cost, good removal efficiencies and easy onsite implementation, point of view as of ecological sight Waste to treat waste.

\section{Conclusion}

The SIWW was found to be better than $\mathrm{FeCl} 3$ for landfill leachates removal. The advantages of the proposed coagulation in addition to pollution removal, process using SIWW were mainly, simplicity, no cost, and easy onsite implementation.

This original coagulant can be successfully selected as coagulant that can used as a process prior to biological treatment.

\section{References}

[1] Kang, K.H., Shin, H.S., Park, H., 2002. Characterization of humic substances present in landfill leachates with different landill ages and its implications. Wat. Res. 36 (16), 4023-4032.

[2] Tatsi, A., Zouboulis, A., 2002. A field investigation of the quantity and quality of leachate from a municipal solid waste landfill in a Mediterranean climate (Thessaloniki,Greece). Adv. Environ. Res. 6, 207-219.
[3] Crawford, J.F., Smith, P.G., 1985. Landfill Technology, Butterworths, London.

[4] Ehrig, H.J., 1984. Treatment of sanitary landfill leachate: biological treatment. Waste Manage. Res. 2, 131-152.

[5] Trebouet, D., Schlumpf, J.P., Jaouen, P., Quemeneur, F., 2001. Stabilized landfill leachate treatment by combined physicochemical-nanofiltration processes. Wat. Res. 35 (12), 2935-2942.

[6] Andreottola, G., Cannas, P., 1992. Chemical and Biological Characteristics of Landfill Leachate. In: Christensen, T.H., Cossu, R., Stegmann, R. (Eds.), Landfilling of Waste: Leachate. Elsevier Applied Science Publishers Ltd., Essex, pp. 65-88.

[7] Diamadopoulos, E., 1994. Characterization and treatment of recirculation-stabilized leachate. Wat. Res., 28 (12), 2439-2445.

[8] Bagchi, A., 1987. Natural Attenuation Mechanisms of Landfill Leachate and Effects of Various Factors On the Mechanisms. Waste Manage. Res. 5 (1), 453-463.

[9] Cossu, R., Andreottola, G., Muntoni, A., 1996. Modelling landfill gas production, in: Christensen, T.H., Cossu, R., Segmann, R. (Eds.), Landfilling of waste: Biogas. E \& FN SPON, London, pp. 237-268.

[10] Rivas, F.J., Beltran, F., Carvalho, F., Acedo B., Gimeno, O., 2004. Stabilized leachates: sequential coagulation-flocculation + chemical oxidation process," J. Hazard. Mat. 116, 95-102.

[11] Amokrane, A., Comel, C., Veron, J., 1997. Landfill leachates pre-treatment by coagulation flocculation. Wat. Res. 31(11), $2775-2782$.

[12] Anouzla, A., Abrouki, Y., Souabi, S., Safi, S. and H. Rhbal. 2009. Colour and COD removal of disperse dye solution by a novel coagulant: Application of statistical design for the optimization and regression analysis, J.Hazard. Mater, 166: 1302-1306.

[13] APHA, AWWA, WEF, 1998. Standards for Examination of Water and Wastewater, 20th Ed. American Public Health Association, Washington DC, USA.

[14] O’Melia, C.R., Becker, W.C., Au, K.-K., 1999. Removal of humic substances by coagulation. Water Sci. Technol. 40, 47-54. 